\section{Teorias da}

\section{Comunicação:}

caminhos, buscas

e interseções

\section{RESUMO}

Nossa proposta é questionar a necessidade de um local "próprio" à comunicação, assim como propor novas discussões, não inviabilizadoras de outros caminhos, outras intersecções, que por ventura apareçam. Contrariamente a uma visão que pensa que a comunicação não tem um objeto, porque ou ele é amplo ou restrito demais, pressupomos que a sua riqueza deriva-se de seu caráter inexato e complexo. Nestes termos, a comunicação não apenas é um tipo de conhecimento específico, como também a sua especificidade é a de transbordar as fronteiras. Sendo assim, ela não se reduz aos meios, pois mais do que signo, a comunicação pode ser pensada a partir do corpo, apoiando-se nas noções de texto (Bystrina) e arquiescritura (Derrida).

\section{ABSTRACT}

Our purpose with this text is to question the necessity of a "proper" place to the communication, as well as to intend new discussions. Contrary to a vision that thinks that communication does not have an object because it is ample or strict excessively, we estimate that its wealth is derived from its inexact and complex character. In these terms, the communication not only is a kind of specifical knowledge, as well as its specificity is to overflow the borders. Being thus, it does more than media, therefore more than sign, the communication can be thought from the body, supporting itself in the notion of text (Bystrina) and archi-writing (Derrida).

\section{PALAVRAS-CHAVE (KEY WORDG)}

- Comunicação (communication)

- Corpo (body)

- Texto e aquiescritura (text and archi-writing)

\section{Tarcyane Cajueiro dos Santos}

Pesquisadora-bolsista da Fapesp em nível de pósdoutorado pela ECA/USP e Membro do Filocom Núcleo de Estudos Filosóficos da Comunicação.
INÚMEROS AUTORES vêm destacando a dificuldade de se trabalhar o objeto da comunicação. Afinal, qual seria a especificidade da comunicação? Teria ela um objeto próprio, ou faria parte de sua característica abarcar todas as áreas teóricas? A comunicação deveria estar especificamente voltada aos seus meios ou ela iria além da técnica, ensejando as diversas práticas sociais da qual faz parte? Estes questionamentos se tornam ainda mais pujantes quando, devido às novas tecnologias, vivemos a implosão de conceitos tradicionais da comunicação, como emissor, canal, mensagem e receptor, que durante anos serviram como guias de estudo e de pesquisa nesta área (Marcondes Filho, 1998).

A discussão aqui empreendida caminha no sentido de questionar a necessidade de um "local próprio" à comunicação, enquanto uma disciplina insular que seleciona uma única dimensão do real em detrimento da complexidade deste, assim como propor novas discussões, não inviabilizadoras de outros caminhos, outras intersecções, que por ventura apareçam. Sendo um conhecimento relativamente novo, que surge com a emergência de uma sociedade em constante processo de mudança e de transformação técnica, não seria um dos traços da comunicação a fugacidade e a interdisciplinaridade de seu objeto? Mesmo concordando com Muniz Sodré, para o qual a vinculação social (o laço atrativo) é o objeto da comunicação, não estaríamos ainda diante de um objeto de difícil apreensão, na medida em que, "o vínculo atravessa limites, atravessa o corpo, os sonhos, o psiquismo do sujeito" (idem, 2001), ao mesmo tempo em que está ligado a todos eles?

A busca de "um olhar próprio" como pré-requisito de status científico parece fa- 
zer parte do repertório epistemológico de ciências cujas especificidades nascem no final do século XVIII e no início do século XIX. Ancoradas no mito da neutralidade científica e da segmentação do saber, elas estão ligadas ao discurso moderno, que se ancora na ilusão da onipotência do homem sobre o meio, a natureza, a cultura e a técnica. Ao considerarem-se detentoras de um aspecto da realidade, como por exemplo, o sociológico, o psicológico ou o econômico, essas disciplinas, pelo menos no seu início, basearam-se em uma visão mecanicista do mundo, que considerava o real como um todo cujas partes deveriam ser fragmentadas, para só assim, posteriormente, ser compreendido. Este modelo que exerceu profunda influência na ciência moderna preserva a

não-mudança, a ausência de história ou de desenvolvimentos complexos da vida do planeta e das sociedades, a tradição e a conservação, em que o presente seria sempre determinado pelo passado, o estável funcionaria como verdade de mudança (Marcondes Filho, 1999:174).

A comunicação, por seu turno, parece pertencer a um outro momento. Vinda à tona por intermédio de uma nova fase da inovação técnica e científica, a comunicação não apenas se torna a utopia da segunda metade do século $X X$, ocupando o antigo lugar de ciências como a sociologia ${ }^{1}$, como também aparece como a ciência ou o saber que sintetiza a passagem da "era do predomínio da lógica da razão à da crise da razão" (Marcondes Filho, 1991: 15), levando consigo todo um manancial que caracteriza este momento. Seu percurso compreende um período de ampla renovação tecnológica, que desencadeou uma mutação técnica global com a aceleração do ritmo de vida e a redução das barreiras espaciais, assim como contínuas organizações sociais. Tais fatos levaram à substituição de uma sociedade disciplinar estruturada sobre a noção de dívida infinita e de dever absoluto, para uma sociedade de controle, assente na informação, na estimulação das necessidades, no sexo, no culto da naturalidade, da cordialidade e do humor e no levar em conta os fatores humanos ${ }^{2}$.

Contrariamente a uma visão que pensa que a comunicação não tem um objeto, porque ou ele é amplo ou estrito demais ${ }^{3}$, pressupomos que a sua riqueza deriva-se de seu caráter inexato e complexo. Nestes termos, a comunicação não apenas é um tipo de conhecimento específico, como também a sua especificidade é a de transbordar as fronteiras, o que condiz com as mais recentes descobertas científicas da física ${ }^{4}$.

$\mathrm{O}$ aparecimento e o desenvolvimento da ciência da comunicação incorporam-se no caminhar de um século que viu surgir, ao lado das mais fantásticas invenções técnicas e descobertas científicas, as mais dolorosas e atrozes destruições humanas, como a primeira e a segunda guerra mundiais, o aparecimento de armas potentes, entre outros acontecimentos que chocaram uma época. Essa imensa lista, que exerceu um grande impacto em diversas sociedades ocidentais do século XX, concorreu para frear as ilusões e os grandes sonhos de uma era moderna, ancorada "nos princípios filosóficos que haviam sido erguidos no começo do século XVII" (Marcondes Filho, 1997: 1).

Nascidos do período entre guerras, da dizimação dos homens por máquinas mais potentes, do aparecimento de regimes totalitários e da sociedade de massa, os estudos da comunicação aparecem em um ambiente mais dinâmico e incerto. Nesse sentido, o desenvolvimento da ciência quântica e relativista e, especificamente, de uma tecnologia a cada dia mais informacional, acabou por gerar, a partir da segunda metade do século $X X$,

a liquidação final das ideologias legitimadoras ou das 'metanarrativas' e por suprimir o respaldo que se baseava numa filosofia especulativa, 
num agir ético-político, passando a uma legitimação em si mesmo, segundo seus parâmetros (Marcondes Filho, 1997: 6).

Como não poderia deixar de ser, as teorias da comunicação foram influenciadas por esses desfechos, abrindo espaço para que os seus estudos pudessem ter características cada vez mais interdisciplinares e menos objetivantes. Deste modo, a ilusão de onipotência, isto é, a crença no sujeito como portador da história e da razão compreendida como cópia do real, desagrega-se. Contudo, a corrosão dos conceitos iluministas e da própria ciência moderna guiada pelo determinismo, pela causalidade e objetividade, não ocorre da noite para o dia $^{5}$. Dela faz parte um longo movimento de autonomização da técnica, que levou o homem à periferia, marcando a sua vida social, cultural e política por fenômenos comunicacionais e, posteriormente, informacionais, na medida em que estes se tornaram cada vez mais presentes no seu cotidiano. Esse processo, que culmina com um novo modelo comunicacional, onde a técnica parece ocupar o lugar da comunicação humana interpessoal, brota sob os auspícios do projeto da modernidade ${ }^{6}$ e consolida-se em uma sociedade fragmentada, regida pelo imperativo da velocidade. Pois, no momento em que o processo de racionalização sobre o qual se ancora a modernidade ocorre nas diversas esferas do tecido social, a sociedade passa a ser caracterizada como um conjunto desterritorializado de relações articuladas entre si, dando aos media um papel cada vez maior de cimentador social.

Isso leva a pensarmos a história das teorias da comunicação, assim como o seu momento atual, a partir das visões de mundo propostas por Sfez em seu livro Crítica da comunicação. Segundo esse autor, o estudo da comunicação e a sua percepção pela sociedade compreendem três metáforas: a representação, a expressão e a confusão. Por meio delas podemos, grosso modo e com alguma limitação, distinguir os modelos teóricos, contextualizando-os, além de, a partir da reflexão daí derivada, propor questionamentos.

Essas três visões de mundo da comunicação são pensadas neste artigo através dos contextos social, histórico e cultural sobre os quais as escolas da comunicação se destacaram, bem como por meio dos contextos científico e tecnológico a elas relacionados. Pressupomos que a partir daí é possível apontar qual o processo comunicativo que subentende cada escola.

Encontraríamos, ao perfazer a curta história desta área, momentos do seu desabrochar como um tipo de conhecimento que inicialmente estaria aprisionado a outras disciplinas, tendo em seguida um posicionamento mais autônomo, adquirindo uma certa especificidade. Esse seria não o de um copilador, mas o de um conhecimento que, dialogando com outras disciplinas, buscaria criar um novo olhar, uma nova perspectiva pautada pela busca da interdisciplinaridade. Historicamente, podemos apontar três períodos. Os anos 1920, com a expansão do rádio e do cinema nos países desenvolvidos; os anos do pós-guerra, com a discussão mais detalhada, com pesquisas científicas acerca dos efeitos sociais e políticos da expansão dos meios de comunicação de massa; e o fim do século, com o aparecimento de novas tecnologias de comunicação e o desabamento das teorias defendidas nos anos do pós-guerra, gerando um clima de perplexidade e desnorteamento por parte dos pesquisadores.

Se voltarmos para os estudos comunicacionais, em um primeiro momento, uma perspectiva bastante simplista do processo comunicativo se conjuga ao que Lucien Sfez (1994) chama de visão de mundo da representação, em que o homem domina a máquina e está com ela para os seus fins.

Na proeminência da razão e da dualidade cartesiana - que se baseia na distinção entre o corpo e o espírito, o sujeito e o objeto -, a representação parte do esquema clássico da comunicação: o emissor, a mensa- 
gem e o receptor, com a dominação do primeiro e a passividade deste último. Conjuga-se a essa visão não somente a crença na ciência moderna como também a novidade do fenômeno da comunicação de massa e o aparecimento das experiências totalitárias que se coadunam com a tese de que "cada elemento do público é pessoal e diretamente atingido pela mensagem" (Wolf, 1999: 21).

Contemporânea de uma época em que os meios de comunicação de massa eram fenômenos novos, assim como novo era o aparecimento de regimes totalitários que utilizavam esses meios, a primeira teoria da comunicação, a teoria hipodérmica, "defendia uma relação direta entre a exposição à mensagem e o comportamento" (Wolf, 1999:25). Ao considerar que o novo fenômeno da época, a massa, era uma organização social em que os indivíduos estariam isoladamente expostos às mensagens $e$ separados entre si, esta teoria via a relação dos homens com os meios de comunicação como baseadas na fórmula reduzida do estímulo-resposta.

Acrescem-se à teoria hipodérmica as teorias de bases sociológica e psicológica, surgidas no pós-guerra, cujo enfoque prioriza questões como os efeitos, a manipulação, a persuasão, a formação de opinião, a influência dos meios de comunicação e a mudança de comportamentos. Tais estudos perpassam os anos 1930, 1940, 1950 e até mesmo os 1960. Apesar de serem teorias distintas, abrangendo perspectivas marxistas, como por exemplo a teoria crítica e a teoria da dependência, assim como empírico-behavioristas e empírico-funcionalistas, elas têm um aspecto em comum: elegem o emissor como o principal expoente da comunicação. A importância conferida ao emissor é tão grande que mesmo descobrindo a existência de filtros entre este e o receptor, tais teorias ainda mantêm o esquema de causa e efeito presente na teoria hipodérmica, bem como no processo comunicativo da teoria da informação de Shan- non e Weaver. Nas palavras de Sfez, neste modelo:

A comunicação é a mensagem que um sujeito emissor envia a um sujeito receptor através de um canal. O conjunto é uma máquina cartesiana concebida com base no modelo de bola de bilhar, cujo andamento e impacto sobre o receptor são sempre calculáveis (Sfez, 1994:65).

Apesar do seu posterior aprimoramento por meio do poder dado aos intermediários ou aos receptores, essas teorias, que se baseiam no sentido da representação, trabalham com o pressuposto de que o movimento (emissor-mensagem-receptor) permanece absolutamente íntegro de uma ponta a outra. Tal "como uma bola de bilhar que uma vez enviada atinge seu objetivo e é novamente reenviada com a conservação da plena integridade do movimento" (Sfez, 1994:16), os meios de comunicação traduziriam o mundo, enquanto a sua mensagem perseguiria o seu movimento teleológico sem perdas de seu conteúdo.

Contrastando com esta percepção cartesiana, o exprimir pressupõe uma "visão em que sujeitos e objetos estão ligados" (Sfez, 1994:31). Essa perspectiva, baseada na filosofia de Espinosa defende que estamos no mundo, o fabricamos, assim como ele a nós. Aqui não existe sujeito separado do objeto, homem da máquina. Neste pensamento holístico em que o todo está na parte, que por sua vez está no todo, não há mais a preocupação com o envio e o recebimento íntegro da mensagem. "A figura desta segunda fórmula", afirma Marcondes Filho, "é a criatura, e os signos produtivos como organismos, exprimem a natureza" (1991:16).

As teorias que se inserem nesta visão de mundo não se preocupam com a perda no movimento da bola de bilhar e das máquinas. Os processos comunicativos se dão em espiral, em um movimento perpétuo e inacabado. Pois a comunicação não é vista 
como um simples encaixe. Ela é inserção de um sujeito complexo em um ambiente igualmente complexo. Ambos em um estado de simbiose, na medida em que sujeito e ambiente são parceiros que praticam trocas incessantes. De acordo com Sfez:

Este modelo sustenta que a metáfora orgânica é um modelo lógico. Ele tem uma problemática própria. Não agimos mais com instrumentos com vista a comunicar. Comunicamo-nos diretamente com todo o corpo dos homens e da natureza nas duas dimensões (sincrônica) e do vir-a-ser (diacrônica). (...) A realidade do mundo não é mais objetiva, mas faz parte de mim mesmo (Sfez, 1994: 49;65).

Para Marcondes Filho, a semiologia, com a importância conferida à mensagem, é uma perspectiva de captação orgânica do processo comunicativo. Como não há mais sujeito e tampouco o contexto histórico determina a interpretação do texto, quem manda, o que manda, o que recebe, como recebe, seriam questões totalmente secundárias e sem grande relevância. Nas palavras do autor:

Esta nova forma de interpretação da comunicação encara que homens estão no mundo e devem a ele se adaptar. A linguagem precede os indivíduos e estes pouco interferem nos seus desdobramentos e no seu processo de desenvolvimento. Os meios de comunicação fazem parte do universo assim como o universo está inserido nos meios de comunicação. Ele é sua expressão (Marcondes Filho, 1991:43).

Sfez, por seu lado, chama atenção às pesquisas que dão importância ao receptor como o criador, por meio do ruído das mensagens. Os fatores sociais, culturais e psicológicos do receptor aparecem aqui embevecidos pela atmosfera da expressão. Ao invés de separado do sujeito pela má- quina, o receptor participaria do mesmo ambiente desta, ligando-se a ela e ao emissor por meio do movimento autopoiético. Afinal, "essas máquinas, essas teorias, essas comunicações, esses 'Outros', somos nós que os sustentamos, fazem parte de nós"' (Sfez, 1994:49).

Inserindo-se no rol de uma das pesquisas mais importantes da área de comunicação na América Latina, os estudos sobre recepção e comunicação, iniciados na década de 1980, configuram-se como um exemplo da visão de mundo da expressão. Ao buscarem os condicionantes do sujeito e das mediações que ultrapassam a noção de um determinismo entre o emissor e o receptor, os estudos feitos por essa escola encontram no organismo a sua metáfora. Essa vertente busca reintegrar a cultura e a comunicação, em uma perspectiva em que a produção, o produto e a recepção estejam interligados (Souza, 1995:25).

Por conseguinte, a visão da confusão corresponderia, segundo Marcondes Filho, a uma nova teoria da comunicação, na medida em que o processo de reorganização do mundo promovido pelas novas tecnologias teria tornado os antigos conceitos completamente inviáveis. Nesta perspectiva, os modelos baseados na representação, com a metáfora da bola de bilhar, e na expressão, com a metáfora da criatura, corresponderiam a uma visão ultrapassada dos processos de comunicação. Segundo Marcondes Filho, no "momento em que a comunicação inverte seu papel e perde o sentido de contato com o mundo, ponte e janela que liga indivíduos a fatos" (1991:45), teríamos uma visão que faria sucumbir as visões anteriores, confundido-as, fundido-as.

Dada a importância e a autonomia que a técnica assumiu, sendo fomentadora do que a sociedade compreende como comunicação, a metáfora do Frankenstein é a que prevalece neste modelo. O Frankenstein, presente em uma comunicação cada vez mais tecnológica, encontra seus arautos nos teóricos da inteligência artificial e da ciência cognitiva. Aqui, espírito e tecnologia não são 
antagônicos, pois, sendo o homem uma máquina pensante, "o espírito é construído como um programa" (Sfez, 1994:259).

Do ponto de vista dos media, ocorre algo parecido: máquina e homem são confundidos. Nesse sentido, a televisão, exibindo um espetáculo que supõe uma distância entre o espectador e a cena, não deixa de nos incluir na própria cena, dando-nos a sensação de participarmos do calor e da emoção do evento. A distância geográfica intermediada pela tela catódica apresentase para nós como um dado insignificante e nem um pouco artificial. $\mathrm{Na}$ frente da tevê nos entristecemos, choramos, nos alegramos. $\mathrm{O}$ acontecimento televisionado, que parece espontâneo, nos dá a sensação de participarmos dele, de o vivenciarmos como se realmente estivéssemos lá.

Participamos realmente do evento transmitido pela televisão ou apenas o vemos? Se escolhermos a primeira alternativa, então, estamos no domínio do em da expressão, porque a ligação com os acontecimentos ocorre por meio da simbiose orgânica e direta entre o sujeito e o ambiente, entre o emissor e o receptor. $\mathrm{Na}$ segunda alternativa, por sua vez, estamos no domínio do com da representação, do emissor separado do receptor. Mas quando saímos desses esquemas confortantes e dicotômicos e assumimos que a sociedade disciplinar cedeu espaço para a sociedade de controle, com seus borramentos de fronteiras, então, nos deparamos com um contexto completamente diferente. Neste caso, tomar a expressão pela representação e confundir, como muitas vezes fazemos, o real pela ficção, quando por exemplo temos "a ilusão de estar ali, de ser aquilo, quando não há senão cortes e escolhas que antecedem o olhar" (Sfez, 1996:76), é um fenômeno que já vem sendo pesquisado por teóricos da comunicação como Baudrillard e Virilio.

$\mathrm{O}$ modelo comunicacional que aqui prevalece, segundo Sfez, é o tautismo, misto de tautologia como única verificação: se repito, provo (tão freqüente em nosso noticiário cotidiano) e autismo, surdez, que conforme o autor é uma

doença do autofechamento em que o indivíduo não sente a necessidade de comunicar o seu pensamento a outrem nem de se adequar ao dos outros; seus únicos interesses são os da satisfação orgânica (Sfez, 1996:78).

Exagerada ou "carregada de tintas", a análise da sociedade da comunicação feita por autores dessa corrente, que dizem sermos todos prisioneiros da espiral comunicativa, envia-nos a um impasse. Pois ela amplia o problema das teorias da comunicação, que passam a se ocupar com um objeto excessivamente amplo, na medida em que na sociedade contemporânea amplificada pelas tecnologias, tudo passa a ser comunicação e, por este motivo, nada mais parece sê-lo.

Trata-se, então, não de superar antigas teorias, na pretensão de uma dialética cuja síntese suprema possa abarcar a complexidade do fenômeno comunicacional, mas de apontar um caminho que nos tire do impasse que a visão de mundo Frankenstein nos coloca. Como o próprio Sfez ressalta:

Se seguimos totalmente Baudrillard, nada podemos fazer nem dizer. Todos os atos e todos os nossos enunciados são prisioneiros da armadilha que denunciam. Agir ou escrever é, na verdade, reforçar a armadilha, um pouco como os movimentos desordenados dos que se afundam em areia movediça (Sfez 1994:10).

Não é sem motivo que este objeto se torna muito mais difícil e problemático por estarmos na sociedade da comunicação. Pensar a época em que vivemos é uma tarefa árdua, especialmente quando ela é movida pelo império da velocidade, da constante renovação tecnológica e da reinvenção de modos de vida e de crenças. Contudo, talvez esteja aí uma pista para podermos trabalhar teoricamente a comunicação e seu objeto indefinível sem que precise- 
mos amputá-la. Nesta perspectiva, tal como o sentido, ela parece como um rastro, nos remetendo sempre a outras relações ${ }^{7}$. Ela, em si, não diz nada, não aponta para nada. O seu sentido e objeto emergem dessas relações.

É aqui que o conceito de arquiescritura de Derrida, como um momento de libertação do logocentrismo, aparece enquanto proposta para se pensar a comunicação. A arquiescritura se insinua a partir de outra lógica, não mais sujeita a um logos e a uma verdade, mas a uma abertura, um devir, sem início ou fim, onde tudo se origina pelo intermediário, pelo meio. Nesse sentido, arquiescritura é apenas a "possibilidade originária" da palavra falada e a escrita em seu sentido estrito. Possibilidade, pois não existe origem, mas suplemento, diferança, isto é, algo que substitui as coisas:

Um adiar para outro tempo e um estar se diferenciando. A diferança admite um antes e um depois, mas adia indefinidamente o momento em que essa separação ocorre. Jamais chegaremos a diferença originária que poderia agir como base para a cadeia de significações (Marcondes Filho, op. cit.).

Como não há origem, não há sutura entre opostos, como natureza e cultura, corpo e espírito. O que existe são rastros, indícios nos fazendo reconhecer que algo ou alguma coisa existiu. Aqui não é a presença que comanda, mas seu apagamento, seu simulacro que deixa as pegadas de uma origem que em si nunca pode ser visualizada, pois, o rastro é um vir-a-ser-imotivado ${ }^{8}$.

Por isso, neste artigo, a comunicação é pensada por meio da noção de texto e não de signo. Como enfatiza Derrida, o signo permanece na descendência do logocentrismo, como um fonocentrismo, pois tal noção implica, nela mesma, a distinção entre significado e significante, como duas faces de uma moeda. Isto é, como "proximidade absoluta da voz e do ser, da voz e do sentido do ser, da voz e da idealidade do sentido do ser" (Derrida 1973:14). Proximidade que tem raízes metafísico-teológicas e se vincula a muitos outros sedimentos ocultos, como, por exemplo, a diferença entre o sensível e o inteligível, de um significado "verdadeiro" que acaba remetendo a um logos absoluto.

Como "não há símbolo e signo e sim um vir-a-ser-signo do símbolo" (Derrida 1973:58), a noção de texto se torna mais apropriada para captar o movimento de comunicação. No texto, há algo que possibilita que o autor diga sempre uma "coisa diferente do que ele queria dizer" (idem, ibidem). Isso significa que o texto possui uma estrutura indecidível e ilegível, tal como a cadeia de suplementariedades, em que não há começo nem fim, mas um ponto qualquer inalcançável.

Se pensarmos o texto a partir da perspectiva de Ivan Bystrina, podemos trabalhar ainda mais a comunicação em sua perplexidade, em sua ambigüidade. Segundo esse autor, cada texto pode ter diversos significados e sentidos múltiplos. Tal como uma estrutura arqueológica, as interpretações e as mensagens dos textos "se armazenam à maneira de camadas superposas umas às outras, partindo das mais simples e superficiais às estruturas mais profundas e complexas" (Bystrina 1995: 18), em um movimento de sobreposição e de reenvio.

Bystrina chama atenção ao imbricamento entre a natureza e a cultura no processo de produção de textos. Para esse autor, a "segunda realidade", a cultura, insere-se na "primeira realidade", a natureza, de tal forma que é impossível pensarmos uma sem a outra. Morin é outro autor que fala que a realidade humana é simultaneamente biológica, psíquica e social. Ao defender o pensamento da complexidade, aponta para a relação recursiva, dialógica, complementar e circular entre indivíduo/espécie/ sociedade, onde o homem deve ser entendido em seus diversos níveis, ou seja, como "Homo demens; que Homo faber é, ao mesmo tempo, Homo ludens; que Homo economicus é, ao mesmo tempo, Homo mythologi- 
cus; que Homo prosaicus é, ao mesmo tempo, Homo poeticus" (Morin, 2000:42).

A comunicação, nesta perspectiva, é um fenômeno para o qual convergem e podem ser mobilizadas tanto as ciências naturais como as ciências humanas. E ainda, se pensarmos que hipoteticamente a comunicação ocorre a partir do vínculo, então o corpo tem primazia nesse processo, como elemento primeiro de vinculação. Nosso corpo recebe todo um aparato para ir ao encontro do outro, trocá-lo, partilhar com ele, mas também repeli-lo. É neste encontro entre o meu corpo e o corpo do outro que ocorre o primeiro passo rumo à comunicação. Harry Pross, teórico alemão, chamou atenção à importância do corpo como meio de comunicação. Essa primeira mídia, a primária, segundo o autor, "funde em uma [única] pessoa conhecimentos especiais"'. Isto de tal modo que, segundo Norval Baitello ${ }^{9}$,

esta pessoa torna-se então mídia. (...). Impensável qualquer interação de um indivíduo com outros indivíduos sem o corpo e suas muitas e múltiplas linguagens, os sons, os movimentos, os odores, os sabores e as imagens que se especializam em códigos, conjuntos de regras com seus significados, frases e vocábulos corporais.

Mais ainda, o corpo não é apenas mídia, pois enquanto texto ele está na base de toda comunicação, alterando e sendo alterado por meio de "uma complexa intersecção entre natureza biofísica, natureza social e cultura"10. Assim, como algo vivo, o corpo, que é biológico e semiótico, pode ser a chave para o entendimento do complexo processo de comunicação, na medida em que a sua abertura textual e seu imbricamento de sentido apontam para uma comunicação pensada como acontecimento, superfície de contato ou ponto de confluência. Como todo texto, o corpo "é uma unidade que se complexifica, se altera e se transforma com a história, porque é fruto de diálogo com os outros textos, com outros tempos, com o passado e a sua memória, mas também com o futuro e seus projetos, sonhos e utopias"11.

Ao pensar a comunicação a partir do corpo como texto, estamos nos afastando das metáforas representação, expressão e confusão, trabalhadas por Sfez. Isso porque a concepção de corpo pressupõe uma leitura da comunicação que ultrapasse os meios, afastando-se, desta forma, da idéia de consciência de si. Ora, se seguirmos as pistas deixadas tanto por Bystrina, por meio da noção de texto, quanto por Derrida, em sua arquiescritura, não apenas a comunicação como o próprio sentido deixam de ser uma teleologia passando a fazer parte do plano da ação, de um pensamento-corpo. Pois se os significados e os significantes abafam toda a ação inerente ao pensamento-corpo, as noções de texto e de arquiescritura remetem à de "um corpo pleno, pura imanência, que devora os símbolos e as 'palavras' nele ancoradas como estruturas mofadas e dinamita as duas faces do signo, significante e significado" (Lins, 2002:70).

Deste modo, a compreensão e o mapeamento da comunicação, de suas relações e manifestações, pressupõem pensarmos as diversas conexões que com ela são travadas. Isso porque, mais do que uma essência, a comunicação é um acontecimento, que está sempre se modificando e se antecipando, assim como o objeto maligno de Baudrillard (1996), ao nosso olhar e às nossas tentativas de aprisioná-lo e submetê-lo às prescrições teóricas e metodológicas •

\section{Notas}

1 Se a sociologia, enquanto um conhecimento científico, surge no século XIX; a ciência da comunicação, por sua vez, somente aparece na segunda metade do século XX. Apesar de distintas, ambas parecem perfilar o espírito desses séculos, apresentando não apenas pretensões científicas como também a formulação de visões utópicas, por meio de suas teorias e projetos: seja, por exemplo, aquela da sociologia pautada pelo desejo de uma socie- 
dade harmônica, através do trabalho como categoriachave, ou aquela da comunicação, por meio da técnica e dos seus instrumentos. Mais especificamente, no que diz respeito à sociologia, Benedito afirma que ela “(...) é 0 resultado de uma tentativa de compreensão de situações sociais radicalmente novas, criadas pela então nascente sociedade capitalista. (...) Na verdade, a sociologia, desde o seu início sempre foi algo mais do que uma mera tentativa de reflexão sobre a sociedade moderna. Suas explicações sempre contiveram intenções práticas, um forte desejo de interferir no rumo desta civilização". Martins, Carlos Benedito. 0 que é sociologia. São Paulo, ed. Brasiliense, 1994 (Coleção Primeiros Passos).

2 Para uma análise pormenorizada da ética das sociedades ocidentais contemporâneas vide: Lipovetsky. 0 crepúsculo do dever: a ética indolor dos novos tempos democráticos. Lisboa, Publicações Don Quixote, 1994.

3 França aponta esta discussão. Segundo a autora, 0 objeto da comunicação se, por um lado, erra por sua simplicidade e objetividade, restringindo-se à dimensão técnica e ao papel de suporte dos media, por outro, ele é amplo demais, não podendo, neste sentido, "ser tomado propriamente como um objeto de estudo definidor de uma área, mas como um aspecto central, uma característica e uma dimensão da sociedade contemporânea". França. "Paradigmas da comunicação: conhecer o quê?". Ciberlegenda, Número 5, 2001.

4 Desde 0 seu início, as ciências sociais e humanas têm sido influenciadas pelas descobertas da ciência física, que por sua vez dá suporte à epistemologia da ciência. Temos então "a relatividade desbancando a mecânica newtoniana de espaço e tempo absolutos, a teoria quântica relativizando a controlabilidade das mensu-rações e o caos questionando a previsibilidade". Estas teorias "constituem parâmetros de um novo tempo, com novos atores, novas regras, uma nova organização mental e social". Marcondes Filho. Superciber: a civilização místico-tecnológica do século 21. São Paulo, NTC, 1997, p.12.

5 Ainda hoje a crença nestes princípios continua presente. É como se mesmo cristalizada ou morta esta visão de mundo ainda produzisse efeitos. A este respeito veja Coletivo NTC. Pensar-pulsar: cultura comunicacional, tecnologias, velocidade. Coletivo NTC, São Paulo Ed. NTC, 1996.

6 A modernidade, enquanto uma organização social que corresponde a um estilo de vida e propicia o desenlace do projeto civilizatório, inaugura uma nova maneira de conceber o homem, repercutindo sobre as relações sociais. Esse novo modo de vida, cuja característica principal é a de ser emulada por um conjunto de descontinuidades que descentram o homem, traz consigo a produção de estilos diferentes das instituições sociais tradicionais. Sobre este assunto veja: Anthony Giddens. As conseqüências da modernidade. São Paulo, UNESP, 1991.

7 Segundo Derrida, "a origem, o ponto de partida inicial, é algo inacessível. Trata-se de um lapso, um piparote: mal começou, já mudou; o dia seguinte da festa é semelhante à véspera" [Marcondes Filho, Introdução ao pensamento de Jacques Derrida, mimeo.]. Como não há origem, não há sutura entre opostos, como natureza e cultura. $\mathrm{O}$ que existe são rastros, indícios nos fazendo reconhecer que algo ou alguma coisa existiu. Aqui não é a presença que comanda, mas seu apagamento, seu simulacro que deixa as pegadas de uma origem que em si nunca pode ser visualizada, pois, o rastro é um vir-a-ser-imotivado: a impossibilidade de restituir totalmente a evidência de uma presença originária.

8 "Assim, não seria preciso dizê-lo, o rastro não é mais natural (não é marca, o signo natural, ou o índice no sentido husserliano) que cultural, não mais físico que psíquico, biológico que espiritual. É aquilo a partir do qual um vir-a-ser-imotivado do signo é possível e com ele, todas as oposições ulteriores entre a physis e seu outro" [Derrida 1973: 58].

9 Baitello. "A mídia antes da máquina". JB On-line, Caderno Idéias. Sábado, 16/10/1999.

10 Idem, Ibidem.

11 Idem, Ibidem.

\section{Referências}

BAUDRILLARD, Jean. As estratégias fatais. Rio de Janeiro, Rocco, 1996.

CASTELLS, Manoel. A sociedade em rede (a era da informação: economia, sociedade e cultura, v.1). São Paulo, Paz e Terra, 1999.

COLETIVO NTC. Pensar-pulsar: cultura comunicacional, tecnologias, 
velocidade. Coletivo NTC, São Paulo Ed. NTC, 1996.

DELEUZE, Gilles. Conversações,1972-1990. Rio de Janeiro, ed. 34 Ltda, 2000.

FRANÇA. "Paradigmas da comunicação: conhecer o quê?". Ciberlegenda, Número 5, 2001.

GUATTARI. "Da produção da subjetividade". In: Imagemmáquina: a era das tecnologias do virtual. PARENTE, André (org.). Rio de Janeiro, Ed. Nova Fronteira, 1996.

HARDT, François. "A sociedade mundial de controle". In: Gilles Deleuze: uma vida filosófica. ALLIEZ, Eric (org.). São Paulo, Ed. 34, 2000.

LIPOVETSKY, Gilles. A era do vazio: ensaio sobre o individualismo contemporâneo. Lisboa, Relógio D’Água, 1988.

LINS, D. "A metafísica da carne: o que pode um corpo?". In : Nietzsche e Deleuze: que pode o corpo?. Lins, Daniel e GADELHA, Silva. Rio de Janeiro, Relume Dumará, Fortaleza, CE, Secretaria de Comunicação e Desporto, 2002, pp.67-80.

MARCONDES FILHO, Ciro. Sociedade Frankstein. São Paulo, 1991, mimeo.

_. Sociedade tecnológica. São Paulo, Scipione, 1994.

-Superciber: a civilização místico-tecnológica do século 21: sobrevivência e ações possíveis : texto introdutório. São Paulo: Ática/ECA-USP, 2000.

- Viagem na irrealidade da comunicação: o princípio da razão durante. Cópia, 1999, mimeo.

MARTINS, Carlos Benedito. 0 que é sociologia. São Paulo, ed. Brasiliense (Coleção Primeiros Passos), 1994.

MORIN, Edgar. A cabeça bem-feita. RJ, Bertrand Brasil, 2000

ORTIZ, Renato. Mundialização e cultura. São Paulo, Ed. Brasiliense, 1998.

ROSNAY, Joel de. "O salto do milênio". In: Para navegar no século XXI: tecnologias do imaginário e cibercultura. MARTINS, Francisco \& MACHADO, Juremir (orgs.). Porto Alegre, Sulina/Edipucrs, 2000, pp.217-224.
SFEZ, Lucien. Crítica da comunicação. São Paulo, Loyola, 1994.

SODRÉ, Muniz. "O objeto da comunicação é a vinculação social". PCLA-Volume 3-número 1: outubro/novembro/ dezembro, 2001. Disponível em: <http:// www.umesp.com.br/unesco/PCLA/revista9/entrevista\%209-1.htm>.Acesso em: 10 de nov. 2003.

SOUZA, Mauro Wilton de. "Recepção e comunicação: a busca do sujeito". In: Sujeito, o lado oculto do receptor. SOUZA, Mauro Wilton (org.). São Paulo, Brasiliense, 1995, pp.13-38.

VIRILIO, Paul. A bomba informática. São Paulo, Estação Liberdade, 1999.

_. . O espaço crítico. Rio de Janeiro, Ed. 34, 1993.

WERTHEIM, Margaret. Uma história do ciberespaço de Dante à Internet. Rio de Janeiro, Jorge Zahar, 2001.

WOLF, Mauro. Teorias da comunicação. Lisboa, Presença, 1999.

WOLTON, Dominique. Penser la communication. Flammarion, Champs, 1997.

. Internet et après? Une théorie critique des nouveaux médias. Flammarion, Champs, 2000. 